\title{
The correlations among undergraduate EFL students' reading habit, multiple intelligences, and writing mastery
}

\author{
Ayu Lestari*, S. Sofendi, and Ismail Petrus \\ Master Degree of Language Education, Faculty of Teacher Training and Education Sriwijaya University, Universitas \\ Sriwijaya, Palembang, South Sumatera, Indonesia
}

\begin{tabular}{|c|c|}
\hline \multicolumn{2}{|c|}{$\begin{array}{l}\text { ABSTRACT } \\
\text { This study aims to investigate the correlations among undergraduate EFL students' reading } \\
\text { habit, multiple intelligences, and their writing mastery. It also aims to identify types of reading } \\
\text { habit and multiple intelligences that mostly influence students' writing mastery. In this } \\
\text { correlational study, the data were collected through questionnaires and test. The data were } \\
\text { analyzed by using correlation and linear regression analyses. The results show that there are no } \\
\text { significant correlations between reading habit and writing mastery, between multiple } \\
\text { intelligences and writing mastery, and between predictor variables and criterion variable. } \\
\text { Keywords: reading habit; multiple intelligences; writing mastery }\end{array}$} \\
\hline $\begin{array}{l}\text { Revised: } \\
\text { 14 March } 2018\end{array}$ & $\begin{array}{l}\text { Accepted: } \\
1 \text { April } 2018\end{array}$ \\
\hline $\begin{array}{l}\text { Final Proof Received: } \\
28 \text { May } 2018\end{array}$ & \\
\hline $\begin{array}{l}\text { How to cite (in APA style): } \\
\text { Lestari, A., Sofendi, S., \& Petrus, I. (2018). The } \\
\text { students' reading habit, multiple intelligences, an } \\
\text { Applied Linguistics, 8(1), pp. 110-120. doi: } 10.175\end{array}$ & $\begin{array}{l}\text { g undergraduate EFL } \\
\text { Indonesian Journal of }\end{array}$ \\
\hline
\end{tabular}

\section{INTRODUCTION}

English is an important language. It is used as the international main tool of communication among people who speak various native languages. In short, English has become a lingua franca for communication in business, education, and government. Hammond (2012) states that English is a language that has the most speakers in the world after Mandarin. There are 101 countries and 10 organizations that use English as their official language -such as United Kingdom, United States, South Africa, Singapore, Switzerland, NATO, NAFTA, etc. The total users are about 1000 million people.

Students who learn English must study four skills: listening, speaking, reading, and writing. Each skill is important and has its own significance. For instance, writing is significant because it is a skill of expressing thoughts and ideas in a written form in addition to the oral form. It is needed in the academic world also. Writing allows students to express their ideas, to develop essential critical thinking, and to enhance cognitive functioning. Richards and Renandya (1996) argue that writing allows people to express themselves personally and publicly, to communicate with others, to gather and clarify information, to explore thoughts and feelings, to document and transmit our findings, and to exercise rights and duties as citizens.

Horsburgh (2009, p. 9) defines writing as a laborious activity for students since it is not a natural activity and requires strong motivation and a great deal of practice. Richards and Renandya (2002, p. 303) add that another difficulty in writing is not only in generating and composing the ideas, but also in presenting the ideas into the text. According to Langan (1987) and Gunning (1998), writing is more complex and more abstract than speaking. Writing is not a form of spoken language, as it requires the readers, or the audiences, to understand and to interpret what has been written.

Students must have the ability to understand and to interpret written text. Leonard (2010) states that mastery is practice. It refers to the process where the difficulties become easy. Webster (1992) states that mastery refers to (1) [a] The authority of a master dominion; [b] The upper hand in a contest or competition, superiority, ascendancy; and (2) [a] Possession or display or great

\footnotetext{
* Corresponding author:

Email: ayuelestari39@yahoo.co.id
} 
skill or technique; [b] skill or knowledge that makes one master of a subject comment. Furthermore, Hornby (1995) states that mastery is a complete knowledge or complete skill. He also states that mastery refers to the capability in getting comprehensive knowledge or skill in a subject. It can be concluded that writing mastery refers to the students' ability in transferring what they thought in their mind in the form of text.

To achieve writing mastery, students should read many texts to get ideas to write well. King cited in Lamott (2016) states that if you want to be a writer, you must do two things above all others: read a lot and write a lot. He also states that aspiring writers read wherever and whenever possible. It means that to be a good writer, students have to build their reading habit.

Reading habit is an essential aspect for creating literate society as it shapes personality of an individual, helps to develop proper thinking methods, and create new ideas (Sadan, 2012). In addition, Simanjuntak (1988) states that reading habit is the number of repetitions in given time to read English text. Moreover, Sangkaeo in Annamalai and Murniandy (2013) states that reading habit refers to the behavior, which expresses the interest of reading and taste of reading. Correspondingly, Shen (2006) identifies reading habits as how often, how much, and what readers read. Reading is a great habit, which can change human life significantly. It can entertain, amuse, and enrich people with knowledge and experiences.

According to McShane (2005, p.7), reading and writing are keys to learn all aspects of life. They provide access to get information and knowledge, to intensify intelligence, to facilitate life-long learning, and to open opportunities with the intention of helping readers to improve their knowledge and intelligence. Reading and writing skills are interrelated at either primary, secondary, and/or tertiary levels of education. There is a claimed that " "... good writers are good readers... Good reading is the key to becoming a good writer...Becoming a good writer works together with becoming a good reader' (Kessler, 2006, pp. 5-9). From another perspective, throughout the years of their stay at colleges, university students are expected to spend their time to read various textbooks, journal articles, and other significant reading materials. Thus, they are required to become efficient and competent readers to elicit information from what they read as much as possible and to increase their intelligence.

Intelligence is the ability to acquire and retain knowledge (Brown 2007, p. 108). Traditionally, intelligence is defined and measured in terms of linguistic and logical-mathematical abilities. The theory of multiple intelligences was developed by Gardner (1983). The traditional notion of intelligence based on IQ testing is very limited. Therefore, Gardner proposes nine different intelligences to account for a broader range of human potential. They are verbal/linguistic intelligence, mathematic/logical intelligence, musical intelligence, spatial/visual intelligence, bodily /kinesthetic intelligence, interpersonal intelligence, intrapersonal intelligence, naturalistic intelligence, and existential intelligence. In an attempt to discover whether there is any relationship between multiple intelligences and writing mastery, Marefat (2007) investigated the participants' scores of their essay writing course exam in relation to their MI. The results turned out that kinesthetic, existential, and interpersonal intelligences made the greatest contribution for writing scores. Rahimi and Qannadzadeh (2010) carried out another investigation of the relationship between Iranians' EFL essay writing and their logical/mathematical and linguistic intelligences. Overall, logical/mathematical intelligence was significantly related to the use of more logicalconnectors in their essay writing. Armstrong (2002) states that there are some individual differences of language learners that can influence the extent to which they learn the second or foreign language. One of them is cognitive variable, which is intelligence. Therefore, intelligence is a very important factor in learning English, including the writing skills. Lipi (2013) states that the capacity students' intelligence has proven to affect the outcome of their study, associated with higher academic achievement.

This study was conducted in the Study Program of English Education of Sriwijaya University. In the University, reading and writing are required courses for the EFL students. Based on informal interview with the students who had taken all reading and writing courses, most of the students were not satisfied with their writing mastery. They also think that they still face some difficulties in vocabulary, grammar, and organizing ideas even though they had the background knowledge of writing and techniques or ways to write well in their second semester until the sixth semester. It might happen because some students might have a bad habit in reading. Thus, this study focuses on the relationships among English Education Study Program students'reading habit, multiple intelligences, and writing mastery.

\section{METHOD}

This study is a correlational study. It aims to find out the relationships among students' reading habit, multiple intelligences, and writing mastery. Correlation design is a procedure in quantitative research in which investigator measures the degree of association (relationship) between two or more variables by using statistical procedure of correlation analysis (Creswell, 2005 , p. 52). The procedure of this study included the distribution of reading habit, multiple intelligences questionnaires, and the administration of a writing test to the students. Figure 1 describes the research design of the study. 


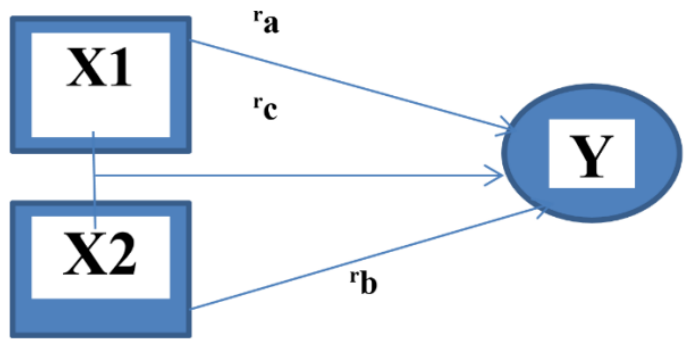

Figure 1 Research Design

$\mathrm{X} 1$ : Students' reading habit

$\mathrm{X} 2$ : Students' multiple intelligences

Y : Writing Mastery

${ }^{r} \mathrm{a}$ : The correlation between reading habit and writing mastery

${ }^{\mathrm{r}} \mathrm{b}$ : The correlation between multiple intelligence and writing mastery

${ }^{r} \mathrm{c}$ : The correlation between the predictor variables (reading habit and multiple intelligences) and the criterion variable (writing mastery)

\section{Population and Sample of Study}

The population of this study was the students of English Education program in the academic year of 2017. The total number of the population was 325 students. The sample was chosen by using purposive sampling. The sample of the study consisted of 76 students.

\section{Techniques of Data Collection}

Two questionnaires and a test were used as the instruments of this study. The first questionnaire was aimed at gathering information dealing with reading habit. There were 20 items, which covered 4 aspects of reading habit. The questionnaire was adopted from Janthong and Sripethpun (2010). All questions were used in this study. Items number 1, 3, 7, 8, 9, 11, 13, 14, 15 , and 20 were intended to check students' reading attitude. Next, items number 5, 6, 16, and 17 referred to reading frequency. Items number 2,4 , and 10 checked students' book read. The last, items number 12, 18, 19 were about reading access. The second questionnaire was intended to collect information about students' multiple intelligences. The questionnaire is McKenzie's (1999). There were nine aspects (verbal/linguistic logical/mathematical, visual/spatial, bodily/kinesthetic, musical, interpersonal, intrapersonal, existential, and naturalistic intelligence). Each of them has 10 items. The first 10 items were intended to check students' natural intelligence. Items number 11 to 20 referred to musical intelligence. Items number 21 to 30 referred to the logical intelligence. Items number 31 to 40 referred to existential intelligence. Items number 41 to 50 referred to interpersonal intelligence. Items number 51 to 60 referred to kinesthetic intelligence. Item 61 to 70 referred to verbal intelligence. Items number 71 to 80 referred to intrapersonal intelligence. The last 10 items were about visual intelligence.

The test was performed to measure students' writing mastery by having them to write an academic essay based on the given topic. The topic is about "The Importance of English in Modern Era". The students should pay attention to the organization of academic essay text: introduction (including general statement and thesis statement), body (main ideas/arguments), and conclusion (summary). The test was conducted for 60 minutes.

\section{Techniques of Data Analysis}

To analyze the data, analysis of frequency was used to reveal the mean score, the standard deviation, and the data distribution. This study also used Pearson Product Moment Correlation to describe and measure the degree of association (or relationship) between two or more variables or sets of scores. Prior to the analysis, normality, homogeneity, and linearity test were conducted.

\section{FINDINGS}

Results of English Learning Motivation Questionnaire Prior to the data analysis by using parametric tests, it should be ensured that the data were normal, linear and homogenous. The Kolmogorov-Smirnov test was employed to test the normality of the data; the Levene's test was applied to see whether the data had the same variance; and the Anova test was performed to see the linear relationship of the data.

The results of normality test for reading habit, multiple intelligences, and writing mastery show that the data are distributed normally because the significance values are higher than .05 . The significance values of reading habit, multiple intelligence, and writing mastery data were $.851, .641$, and .919 respectively. Those data are considered normally distributed.

The results of the homogeneity test between English learning motivation and English mastery, between multiple intelligences and writing mastery, and between predictor variables (reading habit and multiple intelligences) and criterion variables (writing mastery) show that the significance values were $.216, .065$, and .000 respectively. Since the significance value of predictors variables (reading habit and multiple intelligences) and criterion variable (writing mastery) was less than .05 , it was concluded that the variance of 
the data is not equal. Azwar (2001) explains that the homogeneity assumption of the variance is negligible without great risk as long as we have the same sample size in each treatment sample. Conversely, if the sample size in each of treatment is not the same, then the violation of the variant homogeneity assumption can bring consequences for the validity of the inference or inference of the final analysis. On the other hand, the variances of reading habit, writing mastery, multiple intelligences, and writing mastery are equal since the significance values are .216 and .065 .
The results of analysis between reading habit and writing mastery, and multiple intelligences and writing mastery, show that the significance levels of deviation from linearity score are .600 and .717 respectively. Therefore, it can be concluded that the data are linear.

The statistical data were classified into two: the score distribution of reading habit and the aspects of reading habit. As shown in Table 1, the mean score for reading habit (in total) is 72.8421 . The standard deviation of reading habit is 9.51077 . There are $48.68 \%$ students in high category, $50 \%$ in middle/medium category, and $1.315 \%$ in low category.

Table 1. The Score distribution of students' reading habit ${ }_{\text {Total }}(\mathrm{N}=76)$

\begin{tabular}{rlcccc}
\hline \multicolumn{1}{c}{ Interval } & \multicolumn{1}{c}{ Category } & Frequency & \% & Mean & Std. \\
\hline $\mathbf{7 4 - 1 0 0}$ & High & 37 & 48.68 & & \\
$\mathbf{4 7 - 7 3}$ & Middle/Medium & 38 & 50.00 & 72.8421 & 9.51077 \\
$\mathbf{2 0 - 4 6}$ & Low & 1 & 1.32 & & \\
\hline
\end{tabular}

There are four aspects of reading habit: reading attitude, reading frequency, books read, and reading access. Table 2 shows the mean scores of the four aspects of reading habit: reading attitude is 40.1053; and the standard deviation is 13.415 . For reading frequency, the mean score is 14.8289 and the standard deviation is 2.48402. For books read, the mean score is 12.1579; and the standard deviation is 1.85510 . The last, the mean score of reading access is 10.1842; and the standard deviation is 2.18303 .

Table 2. The mean score of sub variable reading habit questionnaire $(\mathrm{N}=76)$

\begin{tabular}{lcc}
\hline \multicolumn{1}{c}{ Sub variable } & Mean & Std. \\
\hline Reading Attitude & 40.1053 & 13.41500 \\
Reading Frequency & 14.8289 & 2.48402 \\
Books Read & 12.1579 & 1.85510 \\
Reading Access & 10.1842 & 2.18303 \\
\hline
\end{tabular}

\section{Results of Multiple Intelligences Questionnaire}

It is revealed that the nine aspects of intelligences are all perceived by the students in different numbers. There are only three students who have one dominant intelligence. They were logical, kinesthetic, and intrapersonal intelligence (see Appendix B). The details are presented in Table 3.

From nine kinds of the multiple intelligences, there are:

1) 7 students have two dominant intelligences;

2) 11 students have three dominant intelligences,

3) 4 students have four dominant intelligences;

4) 9 students have five dominant intelligences;

5) 12 students have six dominant intelligences;

6) 9 students have seven dominant intelligences;

7) 6 students have eight dominant intelligences;

8) 9 students have nine intelligence; and

9) 6 students do not have dominant intelligence -either naturalistic, musical, logical, existential, interpersonal, kinesthetic, verbal, intrapersonal, or visual intelligence.
Table 3. Distribution of students' Multiple Intelligences

\begin{tabular}{clcc}
\hline No. & Multiple Intelligences & Frequency & $\mathbf{0 \%}$ \\
\hline 1. & Naturalistic Intelligence & 0 & $0 \%$ \\
2. & Musical Intelligence & 0 & $0 \%$ \\
3. & Logical Intelligence & 1 & $1.315 \%$ \\
4. & Existential Intelligence & 0 & $0 \%$ \\
5. & Interpersonal Intelligence & 0 & $0 \%$ \\
6. & Kinesthetic Intelligence & 1 & $1.315 \%$ \\
7. & Verbal Intelligence & 0 & $0 \%$ \\
8. & Intrapersonal Intelligence & 1 & $1.315 \%$ \\
9. & Visual Intelligence & 0 & $0 \%$ \\
\hline
\end{tabular}

\section{Results of Writing Mastery Test}

The results show that the lowest score of the writing test is 13.7 out of 30 ; and the highest score is 26.3 out of 30 . For each category, 4 students have excellent writing mastery in the range of 25-30. It means that the four students are knowledgeable to assign topic; the students are to give ideas clearly stated and well organized; the students have few errors of tenses or word order; and they are able to demonstrate writing mechanics. More than a half of the students or 44 students are good in the range of $19-24$, followed by 28 students with the score range of 13-18, enough. It means that the students are categorized good and average. They are able to develop topic given but they still lack of detail. Although the students loosely organized, they are able to stand on main ideas. Those students still have major problems in construction because of several errors of language use. Surprisingly, none of them are in the failed category (scoring 1-6) and the poor category (scoring 7-12). The distribution is presented in Table 4.

Writing mastery consists of ideas, thesis voice audience, organization, mechanic, and vocabulary (see Table 5). The mean score of ideas is 12.8026 , and the standard deviation is 2.00679 . The mean score of thesis voice audience is 12.0526 , and the standard deviation is 1.78807. The mean score of organization is 11.7105 , and the standard deviation is 2.07085 . The next is mechanics. The mean score is 11.3553 and the standard deviation is 1.89529 . On the last rank is vocabulary. Its 
mean score is 12.1711 and the standard deviation is 1.80657 .

\section{Correlation between Reading Habit and Writing Mastery}

In general the result of the correlation coefficient or the r-obtained between the students' reading habit and their writing mastery is -.127 and the significance value is .276 . it is higher than alpha level of 0.05 , showing that there is no significant correlation between reading habit and writing mastery.

Based on the finding, the result of the first research questions show no significant relationship between students' reading habit and their writing mastery (see
Table 6 and Table 7). It indicates that second null hypothesis is accepted.

In addition, since there is no correlation between reading habit (in total) and writing mastery, each aspect of students' reading habit are analyzed and correlated with the total writing by the same formula, Pearson Product Moment Correlation. The result of correlation analysis reveals that from each aspects of reading habit, there is only one aspect that has statistical correlation with the total writing. It is the attitude of reading. The correlation coefficient $(r)$ is -.271 and the significant is 0.05 with $p=0.018$. Therefore, the level of correlation is very weak.

Table 4. Distribution of students' writing mastery

\begin{tabular}{ccccc}
\hline No. & Score Interval & Category & Number of Students & Percentage \\
\hline 1. & $25-30$ & Excellent & 4 & $5.26 \%$ \\
2. & $19-24$ & Good & 44 & $57.8 \%$ \\
3. & $13-18$ & Enough & 28 & $36.8 \%$ \\
4. & $7-12$ & Poor & 0 & $0.0 \%$ \\
5. & $1-6$ & Failed & 0 & $0.0 \%$ \\
& & Mean & & $\mathbf{3 3 . 3 \%}$ \\
\hline
\end{tabular}

Table 5. The mean score of writing mastery aspects $(\mathrm{N}=76)$

\begin{tabular}{lcc}
\hline \multicolumn{1}{c}{ WM Aspect } & Mean & Std. \\
\hline Ideas & 12.8026 & 2.00679 \\
Thesis Voice Audience & 12.0526 & 1.78807 \\
Organization & 11.7105 & 2.07085 \\
Mechanics & 11.3553 & 1.89529 \\
Vocabulary & 12.1711 & 1.80657 \\
\hline
\end{tabular}

Table 6. Correlation between students' reading habit (total) and their writing aspects

\begin{tabular}{|c|c|c|c|c|c|c|}
\hline & RH_TOTAL & IDEAS & THESIS_VOICE & ORGANIZATION & MECHANICS & VOCABULARY \\
\hline Pearson Correlation & 1 & -.102 & -.134 & -.017 & -.035 & -.085 \\
\hline Sig. (2-tailed) & & .380 & 249 & .882 & .765 & 464 \\
\hline $\mathrm{N}$ & 76 & 76 & 76 & 76 & 76 & 76 \\
\hline Pearson Correlation & -.102 & 1 & $.880^{* *}$ & $.836^{* *}$ & $.702^{* *}$ & $.811^{* *}$ \\
\hline Sig. (2-tailed) & .380 & & .000 & .000 & .000 & .000 \\
\hline $\mathrm{N}$ & 76 & 76 & 76 & 76 & 76 & 76 \\
\hline Pearson Correlation & -.134 & $.880^{* *}$ & 1 & $.822^{* *}$ & $.758^{* *}$ & $.790^{* *}$ \\
\hline Sig. (2-tailed) & .249 & .000 & & .000 & .000 & .000 \\
\hline $\mathrm{N}$ & 76 & 76 & 76 & 76 & 76 & 76 \\
\hline Pearson Correlation & -.017 & $.836^{* *}$ & $.822^{* *}$ & 1 & $.760^{* *}$ & $.708^{* *}$ \\
\hline Sig. (2-tailed) & .882 & .000 & .000 & & .000 & .000 \\
\hline $\mathrm{N}$ & 76 & 76 & 76 & 76 & 76 & 76 \\
\hline Pearson Correlation & -.035 & $.702^{* *}$ & $.758^{* *}$ & $.760^{* *}$ & 1 & $.702^{* *}$ \\
\hline Sig. (2-tailed) & .765 & .000 & .000 & .000 & & .000 \\
\hline $\mathrm{N}$ & 76 & 76 & 76 & 76 & 76 & 76 \\
\hline Pearson Correlation & -.085 & $.811^{* * *}$ & $.790^{* *}$ & $.708^{* *}$ & $.702^{* *}$ & 1 \\
\hline Sig. (2-tailed) & .464 & .000 & .000 & .000 & .000 & \\
\hline $\mathrm{N}$ & 76 & 76 & 76 & 76 & 76 & 76 \\
\hline
\end{tabular}

There is one aspect of reading habit that have significant correlation with writing mastery. It is reading attitude. Therefore, this study also tried to find out the correlation between reading habit (total) and aspects of writing. The results reveal that none of the aspects of writing mastery has significant correlation with reading habit (total).

Correlation between Multiple Intelligences and Writing Mastery

In line with reading habit, the result of correlation analysis 
between students' multiple intelligences and their writing mastery show that the correlation coefficient $(r$ $=-.124)$ with the significance value $(.284)$ is higher than 0.05 (see Table 8). It means that $\mathrm{H}_{\mathrm{O}}$ is accepted and $\mathrm{H}_{1}$ is rejected. In short, there is no correlation between the students' multiple intelligences and their writing mastery.

Table 7. Correlation between students' reading habit aspects and their writing (total)

\begin{tabular}{|c|c|c|c|c|c|c|}
\hline & & $\mathrm{Ra}$ & $\mathrm{Rf}$ & $\mathrm{Br}$ & Acc & $\mathrm{Wm}$ \\
\hline \multirow[t]{4}{*}{$\mathrm{Ra}$} & Pearson & 1 & .155 & .200 & $.261^{*}$ & $-.271^{\prime \prime}$ \\
\hline & Correlation & & & & & \\
\hline & Sig. (2-tailed) & & .182 & .083 & .023 & .018 \\
\hline & $\mathrm{N}$ & 76 & 76 & 76 & 76 & 76 \\
\hline \multirow[t]{4}{*}{$\mathrm{Rf}$} & Pearson & .155 & 1 & $.347^{* * *}$ & $.608^{* *}$ & -.024 \\
\hline & Correlation & & & & & \\
\hline & Sig. (2-tailed) & 182 & & .002 & .000 & .838 \\
\hline & $\mathrm{N}$ & 76 & 76 & 76 & 76 & 76 \\
\hline \multirow[t]{3}{*}{$\mathrm{Br}$} & $\begin{array}{l}\text { Pearson } \\
\text { Correlation }\end{array}$ & .200 & $.347^{* *}$ & 1 & .210 & -.122 \\
\hline & Sig. (2-tailed) & .083 & .002 & & .069 & .293 \\
\hline & $\mathrm{N}$ & 76 & 76 & 76 & 76 & 76 \\
\hline \multirow[t]{3}{*}{ Acc } & Pearson & $.261^{*}$ & $.608^{* *}$ & .210 & 1 & .057 \\
\hline & Sig. (2-tailed) & .023 & .000 & .069 & & .625 \\
\hline & $\mathrm{N}$ & 76 & 76 & 76 & 76 & 76 \\
\hline \multirow[t]{3}{*}{$\mathrm{Wm}$} & $\begin{array}{l}\text { Pearson } \\
\text { Correlation }\end{array}$ & $-.271^{*}$ & -.024 & -.122 & .057 & 1 \\
\hline & Sig. (2-tailed) & .018 & .838 & .293 & .625 & \\
\hline & $\mathrm{N}$ & 76 & 76 & 76 & 76 & 76 \\
\hline
\end{tabular}

*. Correlation is significant at the 0.05 level (2-tailed).

**. Correlation is significant at the 0.01 level (2-tailed).

Table 8. Correlation between the students' multiple intelligences and their writing mastery

\begin{tabular}{llrr}
\multicolumn{3}{c}{ Correlations } & \\
\hline & \multicolumn{1}{c}{ RH } & WM \\
\hline RH & Pearson Correlation & 1 & -.124 \\
& Sig. (2-taile[[d) & & .284 \\
& N & 76 & 76 \\
& Pearson Correlation & -.124 & 1 \\
WM & Sig. (2-tailed) & .284 & \\
& N & 76 & 76 \\
& & & \\
& & &
\end{tabular}

Furthermore, since there is no correlation between the multiple intelligences (total) and writing mastery (, each aspect of students' multiple intelligences was analyzed; and the correlation with writing mastery total was analyzed also. The use of Pearson Product Moment Correlation reveals that, of the nine aspects of intelligences, only one type has a very weak correlation with the total writing. It is logical intelligence. The correlation coefficient (r) is -.238 and the significant is 0.05 with $\mathrm{p}=0.038$.

Since only logical intelligence has significant correlation to writing (total) statistically (see Table 9), this study also tried to find out the correlation between multiple intelligences (total) and aspects of writing. The results show that none of writing mastery aspects has significant correlation to multiple intelligences (total) statistically (see Table 10).

\section{Correlation between Predictor Variables (Reading Habit and Multiple Intelligences) and Criterion Variable (Writing Mastery)}

The linear regression analyses were conducted to see the correlation between the predictor variables (reading habit and multiple intelligence) and the criterion variable (writing mastery). The results show that the significance value .345 is higher than significant level .05. It means that there is no significant correlation between the predictor variables and the criterion variable.

\section{DISCUSSION}

Based on the results, the mean score of the reading habit (total) is 72.8421. Most of the students' reading habit mean score is categorized as average (50). In other words, most of the students have a fair reading habit. The result of students' reading habit is influenced by their reading behavior. When they were children, they did not have a good reading habit. However, Norton (1991) highlights that the early age is the golden age of children to promote their language and cognitive development through literature. Norton also suggests that children should be exposed to read frequently. The students, in essential, have good attitude toward reading but they are not avid readers. It can be seen from the results that students got higher score in reading attitude but their got lowest score in reading books. Actually, they are aware of the importance of reading. However, they read only for doing their assignments, preparing the tests, and passing examination or quiz.

Meanwhile, the result of multiple intelligences questionnaire reveals that there are 11 students with three dominant intelligences; and six of them do not have any one of intelligence. It indicates that most students are still lack of knowledge and skills. For example, when the multiple intelligences questionnaire was given to the students, most of them still do not understand the meaning of some items in the questionnaire because the items of the questionnaire use English and contain many new vocabularies. Therefore, it led them to wrong interpretations of the questions. This example shows that they are still learning English in their first until sixth semester. In fact, they are still lack of linguistic intelligence. Armstrong (2002) states that there are some individual differences of the language learners that can influence the extent to which they learn the second/foreign language. One of them is cognitive variable, which is intelligence. It can be implied that in learning English, including in interpreting the items of the questionnaire, the intelligence should be involved. 


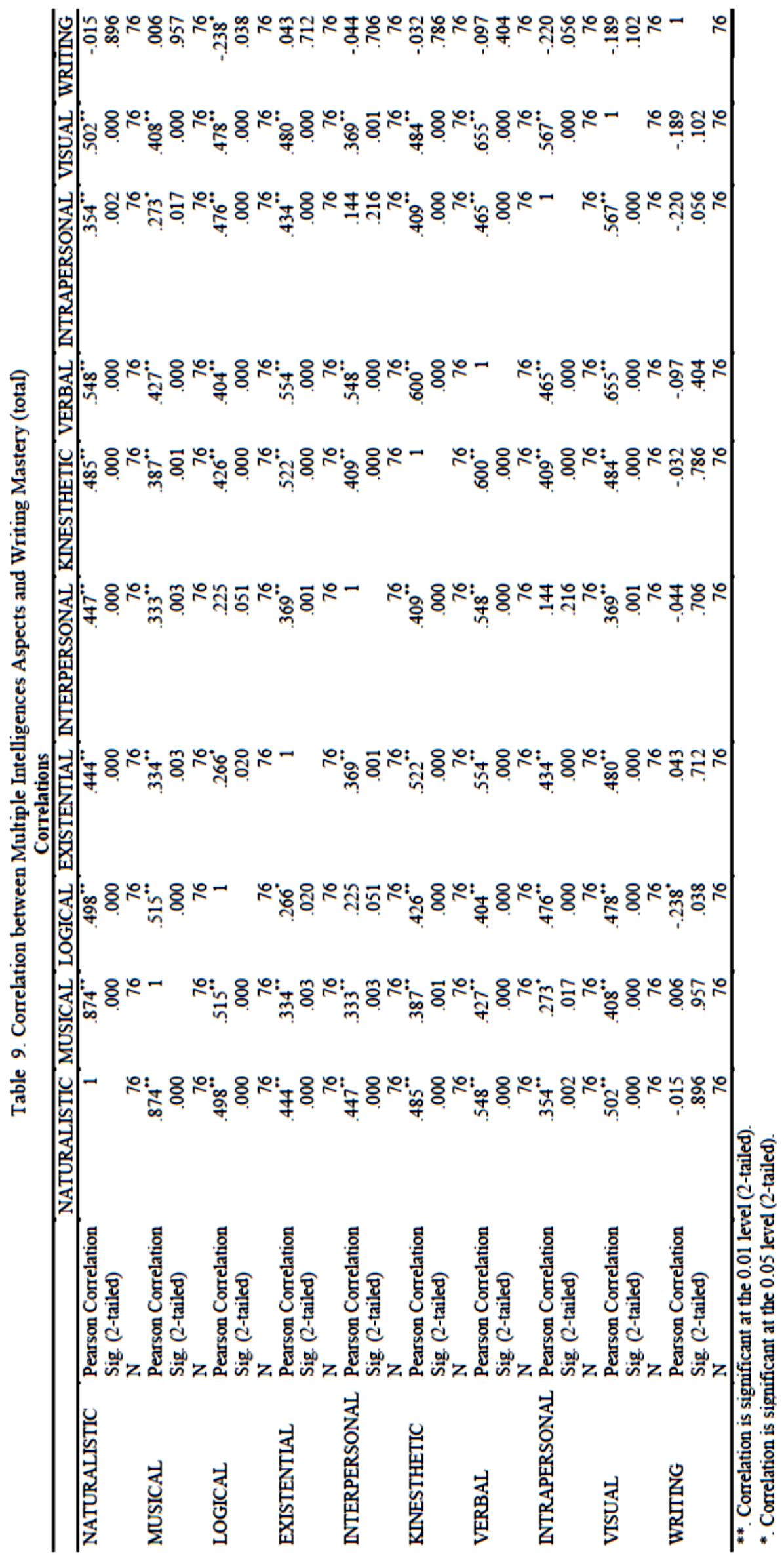


Table 10. Correlation between Students' Multiple Intelligences (Total) and Their Writing Mastery Aspects

\begin{tabular}{|c|c|c|c|c|c|c|c|}
\hline & & $\mathrm{mi}$ & ideas & thesis_voice & organization & mechanics & vocabulary \\
\hline \multirow[t]{3}{*}{$\overline{\mathrm{mi}}$} & Pearson Correlation & 1 & -.205 & -.131 & -.044 & -.054 & -.128 \\
\hline & Sig. (2-tailed) & & .076 & .260 & .708 & .644 & .270 \\
\hline & $\mathrm{N}$ & 76 & 76 & 76 & 76 & 76 & 76 \\
\hline \multirow[t]{3}{*}{ ideas } & Pearson Correlation & -.205 & 1 & $.880^{* *}$ & $.836^{* *}$ & $.702^{* * *}$ & $.811^{* * *}$ \\
\hline & Sig. (2-tailed) & .076 & & .000 & .000 & .000 & .000 \\
\hline & $\mathrm{N}$ & 76 & 76 & 76 & 76 & 76 & 76 \\
\hline \multirow[t]{3}{*}{ thesis_voice } & Pearson Correlation & -.131 & $.880^{* *}$ & 1 & $.822^{* *}$ & $.758^{* *}$ & $.790^{* * *}$ \\
\hline & Sig. (2-tailed) & .260 & .000 & & .000 & .000 & .000 \\
\hline & $\mathrm{N}$ & 76 & 76 & 76 & 76 & 76 & 76 \\
\hline \multirow[t]{3}{*}{ organization } & Pearson Correlation & -.044 & $.836^{* *}$ & $.822^{* *}$ & 1 & $.760^{* * *}$ & $.708^{* *}$ \\
\hline & Sig. (2-tailed) & .708 & .000 & .000 & & .000 & .000 \\
\hline & $\mathrm{N}$ & 76 & 76 & 76 & 76 & 76 & 76 \\
\hline \multirow[t]{3}{*}{ mechanics } & Pearson Correlation & -.054 & $.702^{* *}$ & $.758^{* * *}$ & $.760^{* *}$ & 1 & $.702^{* * *}$ \\
\hline & Sig. (2-tailed) & .644 & .000 & .000 & .000 & & .000 \\
\hline & $\mathrm{N}$ & 76 & 76 & 76 & 76 & 76 & 76 \\
\hline \multirow[t]{3}{*}{ vocabulary } & Pearson Correlation & -.128 & $.811^{* *}$ & $.790^{* * *}$ & $.708^{* * *}$ & $.702^{* * *}$ & 1 \\
\hline & Sig. (2-tailed) & .270 & .000 & .000 & .000 & .000 & \\
\hline & $\mathrm{N}$ & 76 & 76 & 76 & 76 & 76 & 76 \\
\hline
\end{tabular}

**. Correlation is significant at the 0.01 level (2-tailed).

Table 11. Correlation between Predictor Variables and Criterion Variable

$(\mathrm{N}=\mathbf{7 6})$

\begin{tabular}{|c|c|c|c|c|}
\hline Variable & $\mathbf{R}$ & R Square & $\mathbf{F}$ & Sig. \\
\hline Predictor Variables and Criterion Variable & .170 & .029 & 1.080 & .345 \\
\hline
\end{tabular}

Lipi (2013) also states that the capacity of students' intelligence has proven to affect the outcome of their study, and it is associated to higher academic achievement.

Furthermore, the results of students' academic essay writing show that most of the students produce good writing $(57.8 \%)$. It can be assumed that writing is not serious problem for them. They can develop the topic well and understand all the instructions given in the writing test. On the other hand, only $36.8 \%$ are in the average category. It can be because academic essay writing is too difficult for them; and they still consider writing as a problem. There are many aspects that must be taken into account, such as ideas, vocabulary, sentences, spelling, etc. Alwasilah (2005) claims that writing is the most neglected skill of language education in Indonesia. Then, writing habit in Indonesia is lower than reading habit (Khak, 2011). It is proven that due to the lack of publication in international journals, Indonesian universities' ranking dropped drastically in QS World University Rankings 2013 for 100 levels (Nurfuadah, 2013). This study is also in line with Wijaya (2014) that of 136 participants in his research, only 23 students $(16.91 \%)$ who have very good writing skill. However, among other skills, writing is a fundamental language skill that is vital to academic success and a basic requirement for participation in civic life and global economy (Asmari, 2013; and Graham \& Perin, 2007).
Based on the Pearson Product Moment correlation, the correlation coefficient between students' reading habit and writing mastery total is -.127; and the significance value is .276. It is revealed that the significance value is higher than the significant level .05 . it means that $\mathrm{H}_{0}$ failed to reject. It can be concluded that there is no significant correlation between students' reading habit and writing mastery.

This is in contrast with the finding of a study done by Bansa (2014) which indicates that there is a positive relationship between students' reading habit and writing mastery. Reading habit is a way to help students to improve their understanding. In addition, the habit can support students' learning activity, including in writing.

Additionally, a closer observation at the correlation among the variables and the aspects has been performed. The students' writing mastery has a significant correlation with an aspect of reading habit, that is reading attitude with the significance value of .018., despite the fact that the students' reading habit in total do not correlated to the aspects of writing mastery significantly. It might be because not all of the students have a good reading habit and some of them are lazy to read books. This habit can cause problems and difficulties to the students in the learning process, especially in writing. Since there are many things that should be considered, especially when the students want to get good writing results and easy to be understood by the reader. The scores are also varied. After that, not all of the students with good reading habit have good 
writing mastery and able to write well. It can be seen from the results of the writing test. Most of the students faced difficulty in expressing ideas, thesis voice audience, organizations, mechanics, and vocabulary.

Additionally, previous related studies, such as Bansa's (2014), agree that there is no correlation between reading habit and aspects of writing (writing performance). It might be because most of students read at a glance. They do not pay attention fully on vocabulary, mechanic, and organization of a text when they read.

The result of correlation analysis between multiple intelligences in total and writing mastery in total show that the significance value is .284. It is higher than .05 . Thus, the findings prove that $\mathrm{H}_{0}$ is failed to reject. Therefore, there is no significant correlation between multiple intelligences and writing mastery. Further analysis also reveal that none of the aspects of writing mastery is correlated significantly to the multiple intelligences in total. In other analysis, it was found that, among nine types of intelligences, only logical intelligence have significant correlation to writing mastery. Since the significance value of .038 is lower than .05 .

This result was an evident that MI does not play a significant role in improving writing mastery. It could also imply that the students have no specific MI preference when it comes to writing mastery in EFL. It can be happened because the significant correlations might occur due to the variety of students' multiple intelligences. There is no intelligence that is dominant, and the scores are also varied in each aspect of intelligences and writing. Not all of the students with logical intelligence have good writing mastery. Some factors can influence the results of this study (honesty in answering questionnaire, wrong interpretations of questions, etc.).

Additionally, a closer look at the literature review reveals that this study is in accordance with a number of previous studies. This study results are in line with a research conducted by Wijaya (2014) concerning the relationship between multiple intelligence and writing mastery of English Students in Sriwijaya University. There is no significant relationship between the students' multiple intelligence and the students' writing mastery. Meanwhile, for each type of intelligences, Wijaya (2014) reveals that, among different types of multiple intelligences, only bodily kinesthetic has a correlation significantly to writing mastery. Moreover, Marefat (2007) and Sadeghi and Farzizadeh (2012) support that there is no correlation between students' multiple intelligences and aspects of writing. In accordance with Salehi and Gerami (2012), and Naderi, Abdullah, Aizin, and Shahir (2010), none of the intelligence types is correlated in a significant way to students' academic achievement. At the same time, some researches reveal the correlation to writing mastery (Koura \& Al-Hebaishi, 2014; Hanafiyeh, 2013; Saricaoglu \& Arican, 2009; Naseri \& Ansari, 2013; and Ahmadian \& Hosseini, 2012). Moreover, Ayesha and
Khurshid (2013), Ghazi, Shahzada, Gilani, Shabbir, \& Rashid (2011) report that multiple intelligences have positive correlation to academic achievement.

In order to see the correlation between predictor variables (reading habit and multiple intelligence) and criterion variable (writing mastery), the linear regression analyses were conducted. Table 11 shows that the correlation coefficient between predictor variables total and criterion variable total is .170 with the significance value of .345 . It means that $\mathrm{H}_{0}$ is rejected. To sum up, there is no significance correlation between predictor variables and criterion variable. It indicates that whatever the reading habit and multiple intelligences the students have, their writing mastery does not influence much.

Bansa (2014) and Wijaya (2014) claim that there is no significant interaction between reading habit and multiple intelligences on students' writing mastery. This means that the combination of reading habit and multiple intelligences cannot distinguish between high and lower achievers. Students of various reading habits and multiple intelligences do not have different result of writing mastery.

The implications of this study addresses the issues about reading habit, multiple intelligences, and academic essay writing mastery of the students. Even though there is only one aspect of reading habit and multiple intelligences that statistically have significant correlations to academic essay writing mastery. They are reading attitude and logical intelligence.

\section{REFERENCES}

Ahmadian, M., \& Hosseini, S. (2012).A study of the relationship between Iranian EFL learners Multiple Intelligences and their performance on writing. Mediterranean Journal of Social Sciences, 3(1), 111-126.

Alwasilah, A. C. (2005). Developing theories of teaching academic Indonesian to non-1 anguage majors: Ways of collecting and analyzing data. Qualitative Convention in Malaysia, 1-8. Retrieved from http://www.fp.utm.my/epusatsumber/listseminar/7. QRAM05/session2/72.A\%20Chaedar\%20Alwasila h.pdf.

Annamalai, S., \&Murniandy, B. (2013).Reading habit and attitude among Malaysian politechnique students. International Online Journal of Educational Sciences, 5(1), 32-41.

Armstrong, T. (2002). 7 kinds of smart: Menemukan dan meningkatkan kecerdasan anda berdasarkan teori multiple intelligence. Jakarta, Indonesia: PT. Gramedia Pustaka Utama.

Asmari, A.A. (2013). Investigation of writing strategies, writing apprehension, and writing achievement among Saudi EFL - major students. International Education Studies, 6(11), 130-143.

Ayesha, B., \& Khurshid, F. (2013). The relationship of multiple intelligence and effective study skills with 
academic achievement among university students. Global Journal of Human Social Science Linguistics \& Education, 13(1), 20-32.

Azwar, S. (2001). Asumsi-asumsi dalam inferensi statistika. Buletin Psikologi, 9 (1), 8-17. Retrieved from

https://journal.ugm.ac.id/buletinpsikologi/article/vi ew/7436/5778

Bansa, Y. A. (2014). The correlations among reading habit, writing efficacy, and writing performance of English Literature Department students of IAIN Sultan Thaha Saifuddin Jambi (Magister's Thesis). Sriwijaya University, Palembang, Indonesia.

Brown, H. D. (2007). Principles of language learning and teaching $\left(5^{\text {th }}\right.$ Ed.). New York, NY: Longman.

Creswell, J. W. (2005). Educational research: Planning, conducting, and evaluating quantitative and qualitative research (2nd ed.). Upper Saddle River, NJ: Pearson Education, Inc.

Gardner, H. (1983). Frames of mind: The theory of multiple intelligences. New York, NY: Basic Books.

Ghazi, S. R., Shahzada, G., Gilani, U . S., Shabbir, M. N., \& Rashid, M. (2011). Relationship between student's self perceived multiple intelligences and their academic achievement. International Journal of Academic Research, 3(2), 619-123.

Graham, S., \& Perin, D. (2007). Writing next: Effective strategies to improve writing of adolescents in middle and high schools-A report to Carnegie Corporation of New York. Washington, DC: Alliance for Excellent.

Gunning, T. C. (1998). Assessing and correcting reading and writing difficulties. Boston: Allyn and Bacon.

Hammond, A. (2012). The most widely spoken language (Blog post).Retrieved from http://blog.esl-languages.com/blog/esl/mostspoken-languages-world/.

Hanafiyeh, M. (2013). The relationship between Iranian EFL learners' multiple intelligences and success in foreign language learning. Asian Journal of Management Sciences and Education, 2(1), 97105.

Hornby, A. S. (1995). Oxford advanced learner's dictionary of current ( $5^{\text {th }}$ ed.). Oxford: Oxford University Press.

Horsburgh. (2009). New Oxford modern English. Karachi: Oxford University Press.

Janthong, J., \& Sripetpun, W. (2010). English reading comprehension and reading habit improvement: Use of questioning technique. In The 2 nd International Conference on Humanities and Social Sciences April 10th.

Kessler, R. E. (2006). Contemporary issues and decisions: Reading, writing, and thinking in today's world. New York, NY: Longman Pearson Education.

Khak, A. (2011). Minat baca Indonesia rendah. Minat menulis lebih rendah lagi. RIMA: Review of
Indonesia and Malaysia Affairs. Retrieved from http://www.rimanews.com/read/20111123/47177/ minat-baca-indonesia-rendah- minat-menulislebih-rendah-lagi.

Koura, A. A., \& Al-Hebaishi, S. M. (2014). The Relationship between multiple intelligences, selfefficacy and academic achievement of Saudi gifted and regular intermediate students. Educational Research International, 3(1), 48-70.

Lamott, A. (2016). 3 famous writers on the relationship between reading and writing (Blog post).

Retrieved from http://file:///H:/referensi\%20Lamoond.html.

Langan, J. (1987). College writing skill. Florida: Atlantic Community College.

Leonard, G. (2010). Mastery: The keys to success and long term fulfilment. New York: Dutton.

Lipi, I. (2013). Student intelligence and academic achievement in Albanian universities: Case of Vlora University. Acta Universitatis Danubius, $5(2), 48-58$.

Marefat, F. (2007). Multiple Intelligences: Voices from an EFL writing class. Pazhuhesh-e Zabanha-ye Khareji, 32 (special issue in English), 145-162.

McKenzie, W. (1999). Multiple intelligences survey. Retrieved from vobs.at

McShane, S. (2005).Applying research in reading instruction for adults. Washington, DC: The National Institute for Literacy, Department of Health and Human Services.

Naderi, H., Abdullah, R., Aizin, T., \& Shahir, J. (2010). Intelligence and academic achievement: An investigation of gender differences. Life Science Journal, 7(1), 83-87.

Naseri, E., \& Ansari, D. N. (2013). The relationship between multiple intelligences and Iranian high school students' L2 writing achievement. International Journal of Psychology and Behavioral Research, 2(5), 282-290.

Norton, S. (1991). Through the eyes of a child: An introduction to children's literature. Boston, MA: Prentice-Hall.

Nurfuadah, R. N. (2013). Ini penyebab kampus RI lemah di dunia. Okezone. Retrieved from http://kampus.okezone.com/read/2013/09/10/373/8 63655/ini-penyebab-kamus-ri-rendah-di-dunia.

Rahimi, A. \& Qannadzadeh, J. (2010). Quantitative usage of logical connectors in Iranians EFL essay writing and logical and linguistic intelligences. Procedia Social and Behavioral Sciences, 54, 2012-2019.

Richards, J. C., \& Renandya, W. A. (1996). Approach and methods in language teaching. Cambridge: Cambridge University Press.

Richards, J. C., \& Renandya, W. A. (2002). Methodology in language teaching. Cambridge: Cambridge University Press.

Sadan, S. (2012). Promoting reading habit. Retrieved from www.cbse.nic.in. 
Sadeghi, K., \& Farzizadeh, B. (2012). The relationship between multiple intelligences and writing ability of Iranian EFL learners. English Language Teaching, 5(11), 136-142.

Salehi, M., \& Gerami, S. (2012). On the relationship between multiple intelligences and achievement among engineering students. English for Specific Purposes World, 35(12), 1-19.

Saricaoglu, A., \& Arikan, A. (2009). A study multiple intelligences, foreign language success and some selected variables. Journal of theory and practice in Education, 5(2), 110-122.
Shen, Y. (2006). Linguistic experience and linguistic habit. Language Learning 12(2).

Simanjuntak, E. G. (1988). Developing reading skill for ESL students. Jakarta: Department Pendidikan dan Kebudayaan.

Webster, M. (1992). Webster's third new international dictionary. Chicago: Encyclopedia Britannia INC.

Wijaya, B. (2014). The correlation among multiple intelligence, writing, and academic achievement in EFL (Magister's Thesis). Sriwijaya University, Palembang, Indonesia. 